\title{
Effect of dimethyl sulphoxide on necrosis of skin flaps in rats
}

\author{
Ivone da Silva Duarte MD, Heitor Francisco de Carvalho Gomes MD, Lydia Masako Ferreira MD \\ Plastic Surgery Division, Surgery Department, Universidade Federal de São Paulo - Escola Paulista \\ de Medicina
}

\section{I da Silva Duarte, HF de Carvalho Gomes, LM Ferreira. Effect of dimethyl sulphoxide on necrosis of skin flaps in rats. Can J Plast Surg 1998;6(2):93-97.}

The effect of dimethyl sulphoxide (DMSO) on necrosis of the distal portion of random skin flaps was studied. Twenty-eight Wistar-EPM rats each had a random skin flap created that measured 10x4 cm. A plastic barrier was interposed between the flap and the bed. Rats in group 1 received distilled water and those in group 2 received DMSO $2 \mathrm{~mL} / \mathrm{kg} /$ day by intragastric lavage for seven days. The percentages of necrotic area were calculated in the two groups, and malondialdehyde (MDA) was measured in the serum, in the samples of normal skin and in the transition region from viable to necrotic skin. Statistical analysis showed that DMSO was efficient in reducing the necrotic areas and MDA values compared with results from group 1. Statistical analysis also revealed that the action of DMSO as an antioxidant can be inferred to be the mechanism responsible for the results obtained.

Key Words: Antioxidants, Dimethyl sulphoxide, Flaps, Free radicals

\section{Effet du diméthylsulfoxyde sur la nécrose de lambeaux cutanés chez le rat}

RÉSUMÉ : L'effet du diméthylsulfoxyde (DMSO) sur la nécrose de la portion distale de lambeaux cutanés aléatoires a été étudié. On a pratiqué sur vingt-huit rats Wistar-EPM un lambeau cutané aléatoire mesurant $10 \times 4 \mathrm{~cm}$. Une barrière plastique a été interposée entre le lambeau et le lit. Les rats du groupe 1 ont reçu de l'eau distillée et ceux du groupe 2 du DMSO à raison de $2 \mathrm{~mL} / \mathrm{kg} /$ jour par lavage intragastrique pendant sept jours. Les pourcentages de nécrose ont été calculés dans les deux groupes et des dosages de malondialdéhyde (MDA) ont été effectués dans le sérum, dans les échantillons de peau normale et dans la zone de transition entre peau viable et peau nécrosée. L'analyse statistique a révélé que le DMSO permettait de réduire efficacement les zones de nécrose et les valeurs de MDA se comparaient aux résultats du groupe 1. À partir de l'analyse statistique, on peut également supposer que l'action antioxydante du DMSO serait le mécanisme responsable de ces résultats.

$\mathbf{I}_{\mathrm{s}}^{\mathrm{n}}$ plastic surgery there are situations of trauma or reconstruction in which the surgeon has to work with ischemia and the subsequent production of free radicals and their deleterious effects. The occurrence of necrosis after a procedure is an extremely negative event, and diminishing its occurrence is of vital importance.

One mechanism of cell death in the presence of reactive oxygen toxic species (ROTS) is lipid peroxidation $(1,2)$, which is the oxidative deterioration of polyunsaturated lipids. The activities of the free radicals can be indirectly meas-

Correspondence and reprints: Dr Ivone da Silva Duarte, Plastic Surgery Division - Surgery Department, rua Napoleão de Barros, 715, $4^{\circ}$ andar, São Paulo - SP - CEP 04024-900, Brazil. Telephone 55-11-937-4231, fax 55-11-571-6579, e-mail isduarte@mandic.com.br ured as the level of malondialdehyde (MDA), the final stable product of lipid peroxidation (3).

A free radical is defined as an atom or molecule with an unpaired electron in its outermost orbit, which gives it peculiar physical and chemical properties (4). Free radicals can transform into many forms, are cytotoxic (5) and are capable of participating in chain reactions that end in tissue necrosis unless they are eliminated by specific compounds (antioxidants) (6).

Dimethyl sulphoxide (DMSO) is a nonenzymatic antioxidant that acts on the hydroxyl radical. It was initially used clinically as an antiphlogistic as a result of its capacity to inhibit neutrophils (7) before its antioxidant activities were recognized. DMSO is a well-known drug that is easy to administer orally and has few side effects in clinical use. 


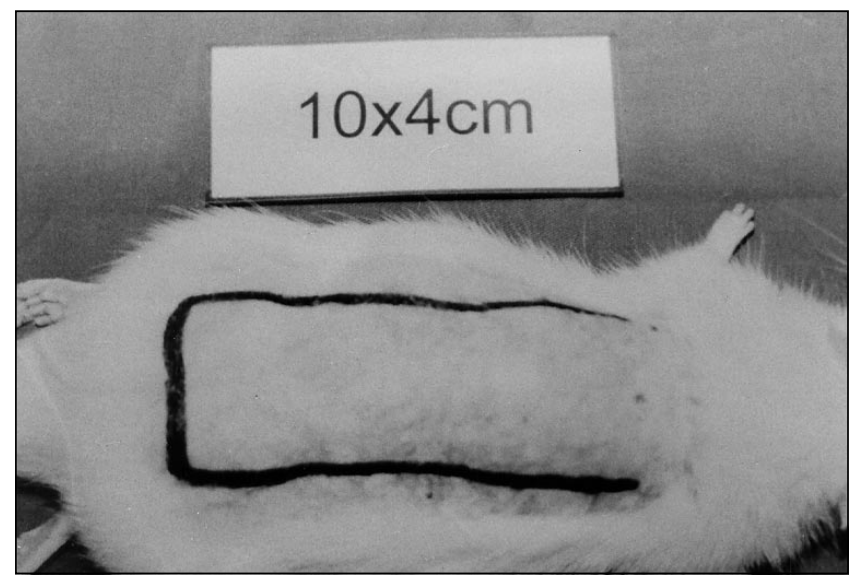

Figure 1) Marking the flap with the standard measurements $(10 \times 4 \mathrm{~cm})$

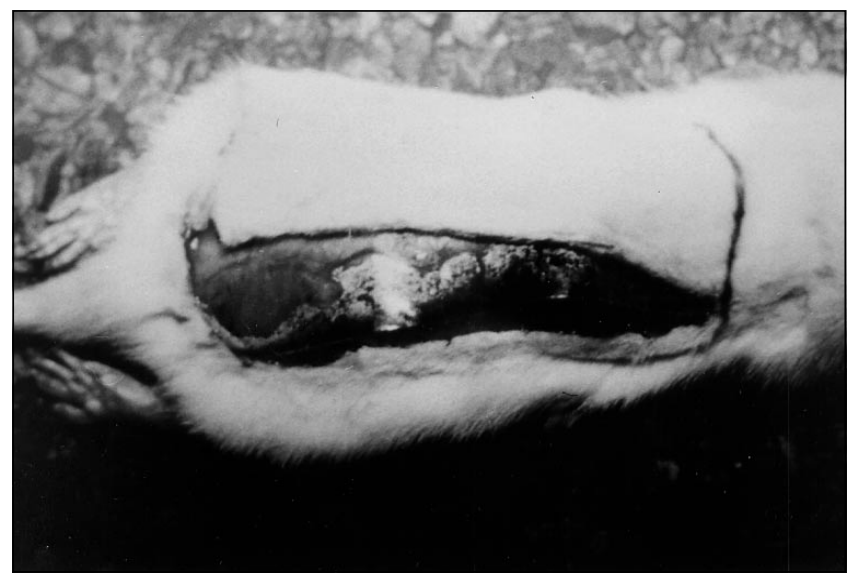

Figure 2) Interposing plastic film $(10 \times 4 \mathrm{~cm})$ between the flap and the bed

The present study was designed to assess the effect of DMSO on necrosis of the distal portion of random skin flaps.

\section{ANIMALS AND METHODS}

A total of 28 Wistar EPM-1 adult male rats, weighing from 185 to $230 \mathrm{~g}$, were randomly assigned to two groups. Animals in group 1 (control, $n=14$ ) received distilled water and those in group $2(\mathrm{n}=14)$ received DMSO $2 \mathrm{~mL} / \mathrm{kg} / \mathrm{day}$ (99.9\%) by gastric lavage. The first dose was administered just before surgery.

Animals were anesthetized with sodium pentobarbital $(40 \mathrm{mg} / \mathrm{kg}$ ) intraperitoneally and then depilated. A random skin flap was elevated, with a cranial base, measuring $10 \times 4 \mathrm{~cm}$ on the back of the animals $(8,9)$ (Figure 1). A plastic barrier with the same dimensions was placed between the flap and its bed (10-12) (Figure 2) and was closed with simple nylon 4-0 stitches (Figure 3).

Rats in group 1 received distilled water and those in group 2 received DMSO in daily doses from the first to the seventh day after the operation. On the seventh day postoperation, the distal necrotic area of the flaps (Figure 4) was checked via the paper template method (11). Blood samples from the portal

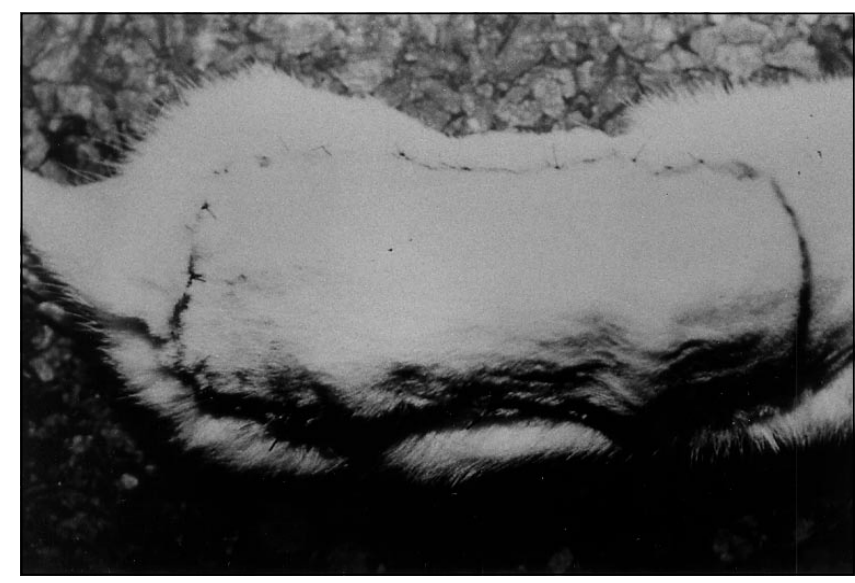

Figure 3) Suture done with simple stitches in 4-0 nylon

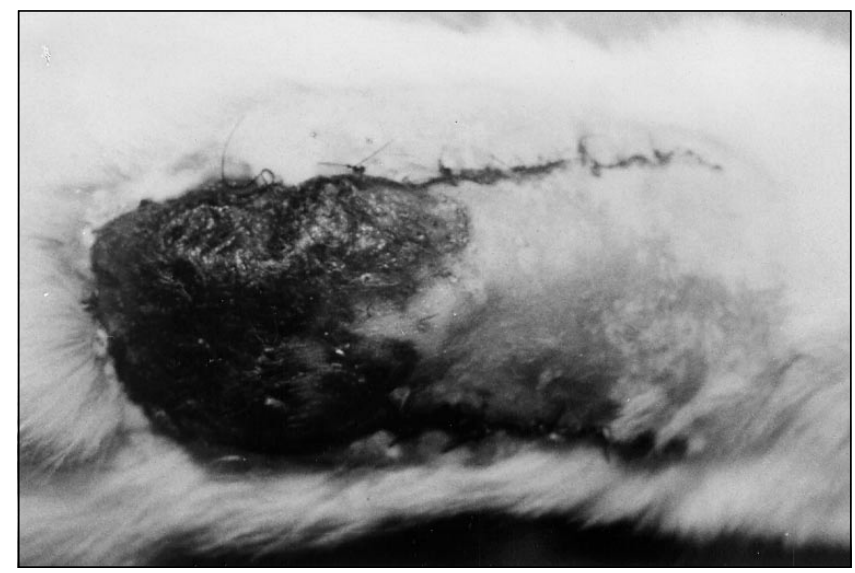

Figure 4) Definition of the border between viable tissue and necrotic tissue

vein of each animal were collected by laparotomy and centrifuged to determine the concentration of MDA in the serum (Figure 5).

Two resections of skin tissue samples, each measuring $1 \times 1 \mathrm{~cm}$, were performed for each animal. One sample was obtained in an area with normal tissue in the upper left portion of the back, at a standard distance of $1 \mathrm{~cm}$ from the flap suture (sample A); another sample with the same measurements was obtained within the flap, in the transition area between viable tissue and necrotic tissue, in the region to the left of this transition (sample B) (Figure 6).

Skin samples were added to potassium chloride $(1.15 \%)$, submitted to homogenization and centrifuged, and the floating result was collected to determine the concentration of MDA. All MDA calculations were done using the thiobarbituric acid method modified by Percário et al (3).

\section{RESULTS}

The necrotic area in group 1 ranged between $51.14 \%$ and $76.67 \%$ (average $65.70 \%$ ), while that in group 2 ranged between $17.86 \%$ and $42.53 \%$ (average $31.37 \%$ ). MDA serum concentrations in group 1 ranged between 494 and $1027 \mathrm{ng} /$ $\mathrm{mL}$ (average $680 \mathrm{ng} / \mathrm{mL}$ ), and between 288 and $712 \mathrm{ng} / \mathrm{mL}$ 


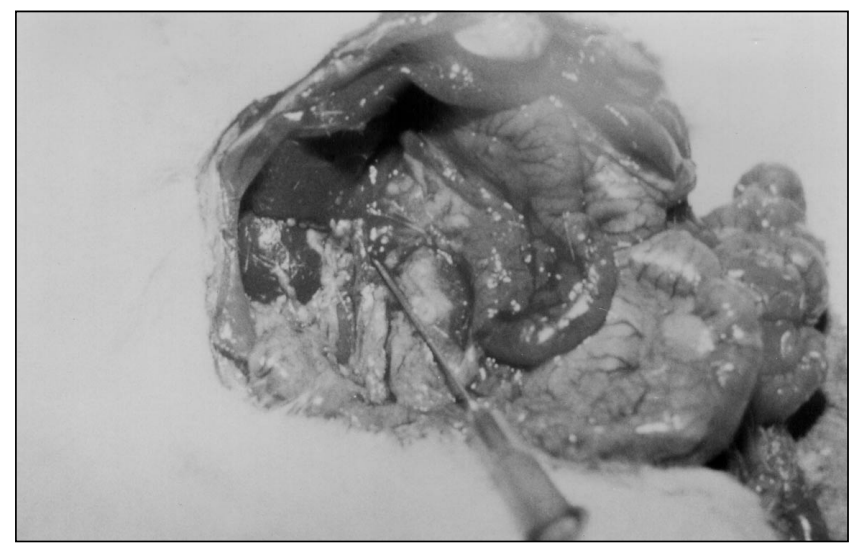

Figure 5) Collection of blood sample through the puncture of the portal vein

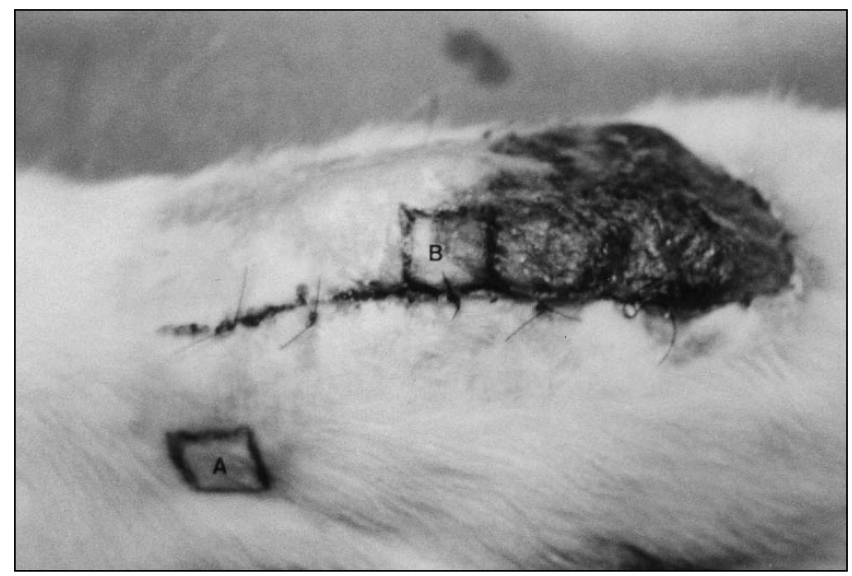

Figure 6) Definition of the dried skin samples. A Sample of normal tissue; $\mathbf{B}$ Sample of the transition from viable to necrotic tissue

(average $475 \mathrm{ng} / \mathrm{mL}$ ) in group 2. The MDA concentration in normal skin samples ranged from 1255 to $3345 \mathrm{ng} / \mathrm{mL}$ (average $2038 \mathrm{ng} / \mathrm{mL}$ ) in group 1 and from 618 to $2031 \mathrm{ng} / \mathrm{mL}$ (average $1006 \mathrm{ng} / \mathrm{mL}$ ) in group 2 . The proportion of MDA in the viable to necrotic transition skin samples ranged from 417 to 1915 (average $1235 \mathrm{ng} / \mathrm{mL}$ ) in group 1 and from 301 to 904 (average $516 \mathrm{ng} / \mathrm{mL}$ ) in group 2. The Mann-Whitney test for independent groups showed that the differences were statistically significant (Tables 1-4).

\section{DISCUSSION}

The presence of ischemia represents a situation of risk and is part of the daily life of the plastic surgeon, whether the cause be traumatic (lacerations and avulsions) or therapeutic (grafts, flaps or microsurgical transplants). The study of ischemic phenomena and their prevention and treatment can increase the percentage of good results of treatment under unfavourable conditions or can reduce the index of complications in these cases.

The actions of oxygen, ROTS and antioxidant substances have been studied in relation to a series of pathologies and to ageing. Each antioxidant has a unique effect on the various levels of cellular defence. In each case, it must be estimated
TABLE 1

Percentage of necrotic area on the seventh postoperative day

\begin{tabular}{lcc}
\hline Animal & Group 1 & Group 2 \\
\hline 1 & 65.93 & 28.90 \\
2 & 51.14 & 18.89 \\
3 & 63.40 & 37.78 \\
4 & 76.67 & 37.65 \\
5 & 67.47 & 27.37 \\
6 & 68.00 & 42.53 \\
7 & 67.44 & 42.00 \\
8 & 71.43 & 19.35 \\
9 & 58.59 & 37.76 \\
10 & 51.43 & 18.75 \\
11 & 75.00 & 38.20 \\
12 & 59.18 & 36.59 \\
13 & 72.50 & 17.86 \\
14 & 71.59 & 36.36 \\
Average & 65.70 & 31.37 \\
\hline
\end{tabular}

Mann-Whitney test, Ucalc $=0.0$ (statistically significant)

TABLE 2

Concentration of malondialdehyde $(\mathrm{ng} / \mathrm{mL})$ in the serum collected on the seventh postoperative day

\begin{tabular}{lcc}
\hline Animal & Group 1 & Group 2 \\
\hline 1 & 774 & 545 \\
2 & 691 & 507 \\
3 & 494 & 385 \\
4 & 780 & 391 \\
5 & 651 & - \\
6 & - & 577 \\
7 & 767 & 700 \\
8 & 576 & 288 \\
9 & 556 & - \\
10 & 496 & 359 \\
11 & 564 & 353 \\
12 & 1027 & 398 \\
13 & - & 481 \\
14 & 780 & 712 \\
Average & 680 & 475 \\
\hline
\end{tabular}

- Insufficient blood samples. Mann-Whitney Test, Ucalc=23.0 (statistically significant)

whether free radicals are being generated in the intracellular and/or extracellular environment. Also, the mechanism of antioxidant action differentiates them; mechanisms can be enzymatic or nonenzymatic, hydrophobic or hydrophillic (13). Thus, for an antioxidant to be efficient, it must not only act against the radicals by a compatible mechanism, but also function in the same setting as the radical.

The loss of a skin flap can be attributed to both extrinsic 
TABLE 3

Concentration of malondialdehyde $(\mathrm{ng} / \mathrm{mL})$ measured in the normal samples of skin on the seventh postoperative day

\begin{tabular}{lcc}
\hline Animal & Group 1 & Group 2 \\
\hline 1 & 2049 & 953 \\
2 & 2012 & 816 \\
3 & 1458 & 2031 \\
4 & 1255 & 1222 \\
5 & 3345 & 916 \\
6 & 2393 & 974 \\
7 & 1784 & 1338 \\
8 & 2116 & 663 \\
9 & 1612 & 1233 \\
10 & 2329 & 618 \\
11 & 2332 & 648 \\
12 & 2339 & 752 \\
13 & 1614 & 725 \\
14 & 1885 & 1194 \\
Average & 2038 & 1006 \\
\hline
\end{tabular}

Mann-Whitney Test, Ucalc $=8.0$ (statistically significant)

\section{TABLE 4}

Concentration of malondialdehyde $(\mathrm{ng} / \mathrm{mL})$ measured in the samples of viable to necrotic transition skin in the seventh postoperative day

\begin{tabular}{lcc}
\hline Animal & Group $\mathbf{1}$ & Group 2 \\
\hline 1 & 1683 & 301 \\
2 & 786 & 362 \\
3 & 884 & 399 \\
4 & 759 & 516 \\
5 & 1683 & 904 \\
6 & 1915 & 326 \\
7 & 1477 & 498 \\
8 & 697 & 455 \\
9 & 417 & 818 \\
10 & 1005 & 522 \\
11 & 1299 & 387 \\
12 & 1661 & 549 \\
13 & 1545 & 756 \\
14 & 1485 & 424 \\
Average & 1235 & 516 \\
\hline
\end{tabular}

Mann-Whitney Test, Ucalc $=17.0$ (statistically significant)

and intrinsic factors. Extrinsic factors include systemic (infection, arteriosclerosis, hypotension or malnutrition) and local (compression, tension or thrombosis of anastomosis) alterations, but inadequate blood flow is the only intrinsic factor, as demonstrated by Kerrigan (14).

In our study we used a model of skin flaps that develops ischemia in the distal portion, with measurements of $10 \times 4 \mathrm{~cm}$
(9). Plastic film was interposed between the flap and the bed, impeding the revascularization of the flap through the bed veins, thus guaranteeing homogeneous conditions of ischemia and necrosis $(10,15)$. The paper template (11) was selected to evaluate the percentage of necrotic area because it is simple and quick, requiring only transparent paper and a precise scale.

DMSO is a pharmacological agent used as an antiphlogistic (inhibiting neutrophils and the biosynthesis of prostaglandins) and an antioxidant (acting on hydroxyl radicals) (16-22). It has been demonstrated that DMSO suppresses the bactericide activity of the neutrophils (7); thus, its antiphlogistic effect is a result of its own antioxidant properties and not of an independent action of this drug.

There have been a great number of studies concerning the use of DMSO in various clinical and experimental applications, using different doses, concentrations and methods of administration (16,18,20-24). According to Rubin (18), DMSO is relatively nontoxic and is well tolerated in high doses by animals.

The only paper we found describing the use of DMSO in flaps is an experimental study by Adamson et al (23), in which DMSO was administered topically. Those authors found a significant reduction in the necrotic area, but they did not correlate the effect with the drug's antioxidant action.

Because there were no references to experimental studies of the use of DMSO in flaps, both pedicled and microsurgical, administered through intragastric lavage, the present study was elaborated to investigate the action of this drug in known and reproducible conditions of ischemia in random skin flaps in rats. DMSO (99.9\%) was used at a dose of $2 \mathrm{~mL} / \mathrm{kg} /$ day because in studies in the literature, the dosage in rats was between 0.5 and $2.0 \mathrm{~mL} / \mathrm{kg} / \mathrm{day}$ for the same concentration and method of application $(18,19,25)$.

In group 1 rats, the average percentage of necrotic area was $65.7 \%$; in group 2 it was $31.37 \%$. The use of DMSO was effective according to the model used, reducing the necrotic area of the distal portion of the flap in group 2 in relation to group 1 .

To verify the reduction in necrotic area that occurred due to the antioxidant effect of DMSO, we tested the concentration of MDA in serum and the skin. MDA was measured on two skin samples in each animal in both groups, using normal skin and viable to necrotic transition skin.

With the ischemia and necrosis provoked in this study, there was a liberation of products and subproducts of lipid peroxidation into the circulation; as a result, it was expected that the levels of MDA in the serum of the animals that received DMSO would be lower than those in the control group. The MDA values in the serum of group 2 animals were significantly lower than those of group 1 . In group 1 , MDA ranged from 494 to $1027 \mathrm{ng} / \mathrm{mL}$ (average $680 \mathrm{ng} / \mathrm{mL}$ ) and in group 2, from 288 to $712 \mathrm{ng} / \mathrm{mL}$ (average $475 \mathrm{ng} / \mathrm{mL}$ ).

In the samples of normal skin, the values of MDA were significantly lower in group 2 (average $1006 \mathrm{ng} / \mathrm{mL}$ ) than those in group 1 (average $2038 \mathrm{ng} / \mathrm{mL}$ ). Similarly, average MDA values obtained in samples of skin from the viable to 
necrotic transition area were lower in group $2(516 \mathrm{ng} / \mathrm{mL})$ than in group $1(1236 \mathrm{ng} / \mathrm{mL})$.

In both groups 1 and 2, we expected lower values of MDA concentration in skin from the viable to necrotic transition region compared with the samples of normal skin; we also expected that group 2's values would be lower than those from group 1. The fact that the concentration of MDA in the samples of normal skin was higher than that in the skin from the viable to necrotic transition region may appear contradictory but must have occurred because in each sample of transition skin there is a large percentage of completely necrotic tissue, where there is no longer a way to measure the concentration of MDA.

After analyzing the results of MDA measurement in serum versus in skin samples, it is apparent that despite the difference between the groups concerning the absolute values found in the serum - which were not as pronounced as those in the skin sample measurements - we can use serum MDA measurement as a way of estimating the efficiency of the dose of DMSO used in other experimental models that are similar to the one used in this study.

DMSO $2 \mathrm{~mL} / \mathrm{kg} /$ day was effective in the reduction of ne-

\section{REFERENCES}

1. Del Maestro RF. An approach to free radicals in medicine and biology. Acta Physiol Scand 1980;492:153-68.

2. Tappel AL. Lipid peroxidation damage to cell components. Fed Proc 1973;32:1870.

3. Percário S, Vital ACC, Jablonka F. Dosagem do Malonaldeído. Newslab 1994;6:46-50.

4. Pryor WA. Free radical reactions and their importance in biochemical systems. Fed Proc 1973;32:1862-9.

5. McCord JM. Oxygen-derived free radicals in postischemic tissue injury. N Engl J Med 1985;312:159-63.

6. Turrens JF, Crapo JD, Freeman BA. Protection against oxygen toxicity by intravenous injection of liposome-entrapped catalase and superoxide dismutase. J Clin Invest 1983;73:87-95.

7. Beilke MA, Collins-Lech C, Solnle PG. Effect of dimethyl sulfoxide on the oxidative function of human neutrophils. J Lab Clin Med 1987;110:91-6.

8. Gomes HFC, Bueno PCS, Scardoeli CAC, et al. Effect of nicotine in randomized skin flaps in rats. Rev Hosp S Paulo - Esc Paul Med 1994;5:13-7.

9. McFarlane RM, DeYoung G, Henry RA. The design of a pedicle in the rat to study necrosis and its prevention. Plast Reconstr Surg $1965 ; 35: 245-8$

10. Kaufman T, Angel MF, Eichenlaub EH. The salutary effects of the bed on the survival of skin flaps. Ann Plast Surg 1985;14:64-73.

11. Sasaki GH, Pang CY. Hemodynamics and viability of acute neurovascular island skin flaps in rats. Plast Reconstr Surg 1980;65:152-8.

12. Siegel S. Estatistica no Parametrica. Mexico: Ed Trillas, 1975:346.

13. Angel MF, Ramasastry SS, Swartz WM, Basford RE, Futrell JW. Free radicals: basic concepts concerning their chemistry, pathophysiology, and relevance to plastic surgery. Plast Reconstr Surg 1987;79:990-7. crosis. In both the serum and skin samples, MDA was significantly lower in the group treated with DMSO (group 2) than in controls (group 1). Thus, it can be inferred that the action of DMSO as an antioxidant was the mechanism responsible for the results observed in group 2.

This study demonstrated the role of the hydroxyl radical in the ischemia of skin flaps in rats and the improvement of the results using an antioxidant that acts specifically on these radicals. It is important to evaluate whether other antioxidants in addition to DMSO act on the hydroxyl radical and are efficient under the same ischemia conditions. In addition, it is necessary to investigate whether there is participation from other radicals in the ischemia in skin flaps, as well as in other plastic surgery procedures, and to determine the antioxidants that are most efficient in the corresponding situations.

In the future, the determination of the ideal antioxidants for clinical use will, together with the use of substances that increase arterial flow to the flaps, broaden the therapeutic resources available to plastic surgeons, contributing to a reduction in ischemic complications in both emergency and elective situations.

14. Kerrigan CL. Skin flap failure: pathophysiology. Plast Reconstr Surg 1983;72:766-74.

15. Ugland O. Flaps and flaps necrosis. Acta Chir Scand 1966;131:408-12.

16. Heikkila RE. The prevention of aloxan-induced diabetes in mice by dimethyl sulfoxide. Eur J Pharmacol 1977;44:191-3.

17. Naito Y, Yoshikawa T, Matsuyama K, Nishimura A, Yagi M, Kondo M. Effects of free radical scavengers on indomethacininduced aggravation of gastric ulcer in rats. Dig Dis Sci 1995;40:2019-21.

18. Rubin LF. Toxicity of dimethyl sulfoxide alone and in combination. Ann NY Acad Sci 1975;243:98-103.

19. Salim AS. Removing oxygen-derived free radicals stimulates healing of ethanol-induced erosive gastritis in the rat. Digestion 1990;47:24-8.

20. Salim AS. Protection against stress-induced acute gastric mucosal injury by free radical scavengers. Intensive Care Med 1991;17:455-60.

21. Salim AS. A possible new approach to the problem of refractory peptic ulceration. A role for free radical scavengers? Scott Med J 1991;36:19-20.

22. Steer ML, Rutledge RE, Powers M, Saluja AK. The role of oxygen-derived free radicals in two models of experimental acute pancreatitis; effect of catalase, superoxide dismutase, dimethylsulfoxide and allopurinal. Klin Wochenschr 1991;69:1012-7.

23. Adamson JE, Horton CE, Crawford HH, Ayers WT. Studies on the action of dimethyl sulfoxide on the experimental pedicle flap. Plast Reconstr Surg 1967;39:142-6.

24. Desai MD, Teres D. Prevention of doxorubicin induced skin ulcers in the rat and pig with dimethyl sulfoxide (DMSO). Cancer Treat Rep 1982;66:1371-4.

25. Dunn SP, Gross MD, Hon R, Grosfeld JL. Superoxide: a critical oxygen-free radical in ischemic bowel injury. J Pediatr Surg $1984 ; 19: 740-4$. 